Britain would have just as much right to protest against the extermination, by the United States, of the buffalo and the beaver.

It has been suggested that the seals might be exterminated, but this would be sawing off the branch with the man on it, unless the proposers of this plan mean by it what I wish to suggest. This is that so many seals be killed on the Islands that there would not be enough left in the seas to make pelagic sealing profitable. It would seem possible to keep a small herd on the Islands and the killing of the small number would be very profitable, as the price of sealskins would doubtless rise. It looks to me as if we had the trump card in our hands and could offer Great Britain almost any conditions on pelagic sealing that we like.

NEw YoRk, November 27, 1897.

P. C. H.

\section{OBSERVATIONS ON THE PHYSIOGRAPHY OF} WESTERN MASSACHUSETTS.

THe following notes on the character and elevation of the Cretaceous peneplain in western Massachussetts were made during a trip in the Berkshire region in the spring of 1897 . The area covered lies between the Housatonic and Connecticut lowlands and south. of the Boston and Albany Railroad.

From map-study alone the tendency is to locate the peneplain by the broadest tracts of level country to be found upon the map and to call what lies above monadnocks. It was found, however, that this estimate placed the peneplain altogether too low. The broad spaces proved on observation to be broad, shallow tracts of etched-out country, and most of what had been supposed from map-study to be monadnocks fell into a very good level skyline. The region contains but few monadnocks, and these of small size; their size and number decreasing from north to south.

In the township of Hinsdale the peneplain lies at a height of 2,050 to 2,100 feet; at Washington Centre it falls to 2,000 feet; and seven miles in a south-southeasterly direction, near Becket Centre, it is but 1,850 feet in height. Between Sandisfield Centre and New Marlborough, about seventeen miles due south of Washington, the height of the peneplain de- creases to 1,750 feet; at Tolland Centre its elevation is about 1,550 feet; and at Blandford Centre, about eight miles to the northeast, the same. By comparison of these points the following conclusions were reached:

(1) The peneplain dips from about northnorthwest to south-southeast.

(2) Its fall in twenty-five miles is about 550 feet, a rate of twenty-two feet to the mile.

An apparent consequence of this slope of the peneplain is the prevailingly south-southeast courses of the streams, great and small, throughout the area. Along the escarpments where the upland falls off into the Housatonic lowland or into the Connecticut lowland the streams naturally follow the steeper gradient and have cut east and west courses some distance back into the upland, though even these streams in their upper courses conform more and more to the habit of the other streams. The long axes of the lakes and ponds also lie prevailingly northwest and southeast, and the majority of the long, straight stretches of road follow the same direction.

Roland B. Dixon, Charles D. DReW.

\section{SCIENTIFIC LITER ATURE.}

The Dawn of Astronomy, a study of the templeworship and mythology of the ancient Egyptians. By J. Norman Lockyer. New York and London, The Macmillan Co. First edition, 1894 ; second edition, 1897. Octavo, pp. 432. Illustrated. Price, $\$ 3$.

Sir Norman Lockyer first gave his attention to the questions treated in this book in the year 1890 and they are stated in his preface somewhat as follows: It is a matter of common knowledge that many of the churches of England are so constructed that their eastern windows face the point of sunrise on the day of the patron saint. For example, the churches dedicated to St. John the Baptist face nearly northeast. The question arises whether the Egyptian temples have a similar orientation to the sun or to some star. This can be completely determined by accurate surveys of the temple sites; by an investigation of the inscriptions, etc.; by a study of the mythology and history of the people; by the calcu- 